\title{
Therapeutic challenge of a paediatric case of Graves' disease with severe ophthalmopathy
}

\author{
Carla Ferreira, ${ }^{1}$ Carla Meireles, $^{1}$ Olinda Marques, ${ }^{2,3}$ Ana Antunes ${ }^{3,4}$
}

${ }^{1}$ Department of Pediatrics, Hospital Sra da Oliveira Guimarães, Guimarães, Portugal

2Department of Endocrinology, Hospital de Braga, Braga, Portugal

${ }^{3}$ Pediatric Endocrinology Unit, Hospital de Braga, Braga,

Portugal

${ }^{4}$ Pediatric Department, Hospital de Braga, Braga, Portugal

\section{Correspondence to}

Dr Ana Antunes, ana.antunes. p@gmail.com

Accepted 28 February 2017
CrossMark

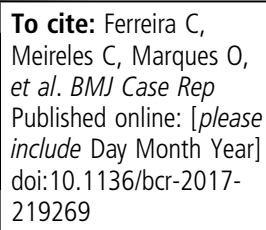

\section{DESCRIPTION}

An otherwise healthy girl aged 4 years was observed because of a 6-month history of tachycardia, polyphagia, chronic cough and agitation. Physical examination revealed hiperhydrosis, exuberant exophthalmia (figure 1) and a palpable, elastic and painless goitre. Laboratory work up showed an increased FT4, low thyroid-stimulating

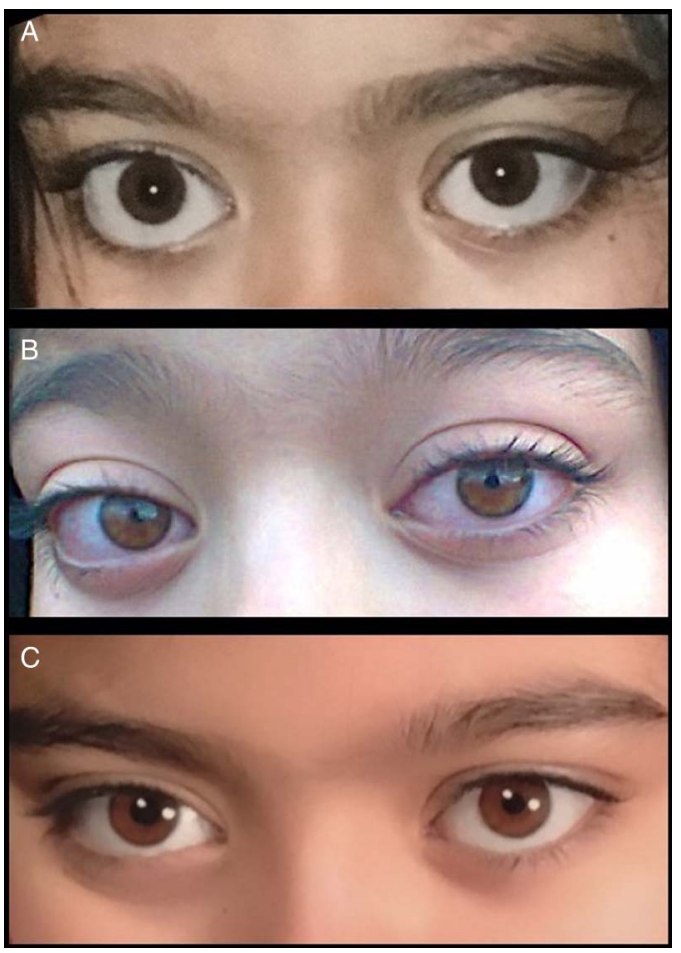

Figure 1 Exophthalmia observed on physical examination at diagnosis time (A). Exophthalmia, eyelid retraction and lagoftalmos at 7 years (B). Actually: no exophthalmia (C). hormone (TSH) and positive thyrotropin receptor antibodies (TRABs) (figure 2), and thyroid ultrasonography demonstrated a diffusely heterogeneous, enlarged gland with no nodules, compatible with Graves' disease. The girl was initiated immediately to treatment with tiamazole (MTZ) and propranolol, and after few months, an euthyroid state was achieved and maintained until 2 years (figure 2). After this period, MTZ treatment was suspended and 1 month later, she returned with restless sleep and daytime agitation. Laboratory work up showed a $\mathrm{TSH}<0.005 \mu \mathrm{U} / \mathrm{mL}, \mathrm{T} 4 \mathrm{~L}$ of $0.98 \mathrm{ng} / \mathrm{mL}$ and a positive TRABs and MTZ treatment (figure 2) was reintroduced.

At 7 years, she presented with worsening exophthalmia, eyelid retraction, lagophthalmos (figure 1)

\section{Learning points}

- A characteristic feature of Graves' disease is ophthalmopathy. In fact, its presence should raise immediate suspicion of Graves' disease. Its cause remains uncertain, but a shared antigen in the orbit and thyroid gland, such as the thyrotropin receptor, seems to be a probable cause.

- Ophthalmopathy treatment depends on the phase and severity of the disease. The majority of patients only require conservative measures, although sometimes corticotherapy is needed.

- This case demonstrates a therapeutic challenge of a paediatric case of Graves' disease, where the difficulties of assisting remission with medical treatment, prompted to a definitive treatment. In this case, surgery was preferred because of the large thyroid tissue volume and iodine $^{131}$ risks of exacerbate ophthalmopathy.

Figure 2 Longitudinal evaluation of thyroid function (FT4 and thyroid-stimulating hormone), thyrotropin receptor antibodies levels and treatment performed from the diagnosis moment to present time.

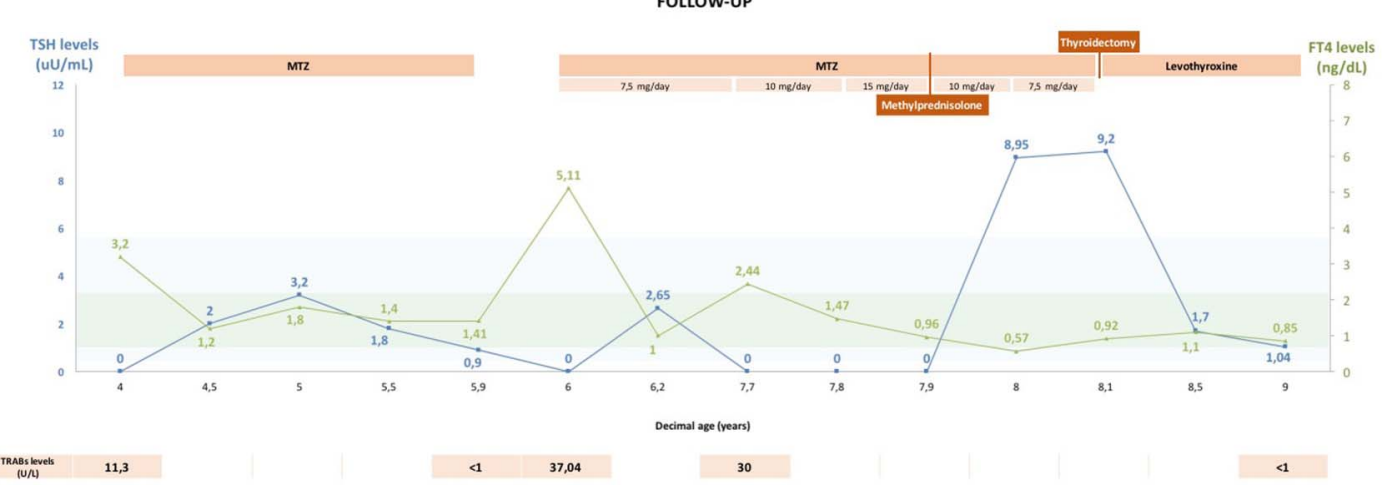


and a bigger goitre (left lobe $17 \times 50 \times 19 \mathrm{~mm}$, right lobe $20 \times 55 \times 22 \mathrm{~mm}$ ), with worsening of hyperthyroidism and although MTZ dosage was adjusted (figure 2), the girl developed asymptomatic bilateral papilloedema. Orbit CT scan showed compressive optic neuropathy and she was started immediately on intravenous methylprednisolone with favourable clinical response. Two months later, she was submitted to a total thyroidectomy and was started on levothyroxine. One year later, she remains well, without exophthalmos (figure 1).

Graves' disease is a rare, but a leading cause of paediatric hyperthyroidism. ${ }^{1}$ A typical finding is Graves' ophthalmopathy, often mild and self-limited, but in $3-5 \%$ of cases is associated with risk of vision loss. ${ }^{2} 3$ The first-line treatment is synthetic antithyroid but when remission is not achieved, definitive treatment should be considered. The choice between surgery and iodine $^{131}$ is individualised, considering the patient and the disease characteristics. ${ }^{1}$
Contributors CF is responsible for planning, conduct, conception and design, data collection, manuscript writing, analysis and interpretation of data. CM is responsible for conception and design, critical review of the content of the manuscript, analysis and interpretation of data. AA and $\mathrm{OM}$ are responsible for conception and design, critical review of the content of the manuscript, analysis and interpretation of data.

Competing interests None declared.

Patient consent Obtained.

Provenance and peer review Not commissioned; externally peer reviewed.

\section{REFERENCES}

1 Ross DS, Burch HB, Cooper DS, et al. 2016 American Thyroid Association guidelines for diagnosis and management of hyperthyroidism and other causes of thyrotoxicosis. Thyroid 2016;26:1343-421.

2 Smith TJ, Hegedüs L. Graves' disease. N Engl J Med 2016;375:1552-65.

3 Bartalena L, Baldeschi L, Dickinson AJ, et al. Consensus statement of the European group on Graves' orbitopathy (EUGOGO) on management of Graves' orbitopathy. Thyroid 2008;18:333-46.

Copyright 2017 BMJ Publishing Group. All rights reserved. For permission to reuse any of this content visit

http://group.bmj.com/group/rights-licensing/permissions.

BMJ Case Report Fellows may re-use this article for personal use and teaching without any further permission.

Become a Fellow of BMJ Case Reports today and you can:

- Submit as many cases as you like

- Enjoy fast sympathetic peer review and rapid publication of accepted articles

- Access all the published articles

- Re-use any of the published material for personal use and teaching without further permission

For information on Institutional Fellowships contact consortiasales@bmjgroup.com

Visit casereports.bmj.com for more articles like this and to become a Fellow 